\title{
Blood groups as risk factor of hypertension in Arar population, Northern Saudi Arabia
}

\author{
Taif Shayish N Alanazi, Khalid Nadi M Alanazi, Wael Ayad O Alruwaili, Mohammed \\ Abdullah A Alanazi, Ahmed Nawfal M Alshammari, Abdulaziz Saqer A Alanazi, Zuhur Naif \\ Alazmi, Anwar Ayed Thani Alanazi, Ruba Mohammed Mahdi Almijlad, Anwar Suwailem \\ Almutairi, Almajd Mateb Nafa Alenzi
}

\author{
Faculty of Medicine, Northern Border University, Arar, kingdom of Saudi Arabia
}

\begin{abstract}
:
Background: Hypertension is a disease that has a huge impact on the health of communities. Familial patterns of hypertension suggests genetic factor as an another important non-modifiable predisposing factor, and $\mathrm{ABO}$ blood group is one of such factors which needs to be investigated in more details. Objective: to evaluate the prevalence of hypertension in various $\mathrm{ABO}$ and $\mathrm{Rh}$ blood group subjects, and to explore any association between $\mathrm{ABO}$ and Rh blood groups with hypertension. Methods: A cross-sectional study was conducted in Arar city, Northern Saudi Arabia. It included 312 participants from the general population of Northern Saudi Arabia. Data were collected by a pre-designed online questionnaire which was distributed among the population. It was self-administered, after a brief explanation of the idea of the research. The questionnaire included the clear questions to collect the relevant data. Results: the study included 312 participants $28.8 \%$ aged $30-39$ years, $26.0 \%$ aged 40 year or more, $85.3 \%$ were females and $79.2 \%$ were highly educated. In the studied sample, $38.1 \%$ had O blood group, $30.1 \%$ had B blood group, $26 \%$ had A blood group and 5.8\% had AB blood group. About fifth $(20.5 \%)$ of studied sample had hypertension; from them $20.3 \%$ group $\mathrm{A}, 7.8 \% \mathrm{AB}, 25 \% \mathrm{~B}$ and $46.9 \%$ group $\mathrm{O}$. The present study found that there was no significant association between hypertension and blood groups as risk factors $(\mathrm{P}=0.274)$. Among hypertensive cases $85.9 \% \mathrm{Rh}+\mathrm{ve}, 14.1 \% \mathrm{Rh}$-ve, there was no significant association between hypertension and $\mathrm{Rh}$ factor $(\mathrm{P}=489)$. Conclusion: The findings of the present study indicated that in Arar city population, we could not find any evidence that particular ABO blood group was more susceptible to develop hypertension.
\end{abstract}

Key words: $\mathrm{ABO}$ blood group, blood pressure, hypertension, Arar city, positive Rh and negative Rh, risk factor, association.

Introduction:

Hypertension is a disease that has a huge impact on the health of communities. It is widespread in the Arabian Gulf area, Middle East region, and the whole world ${ }^{[1]}$. Since uncomplicated hypertension is an asymptomatic condition, many people are unaware that they have high blood pressure. Therefore, diagnosis of hypertensive patients is of paramount importance. However, to diagnose hypertension, recognition of its probable risk factors would be important ${ }^{[2]}$. The ABO blood group system, which was the first human blood group system to be discovered, is exclusively and integrally heritable, genetically determined at conception and remain fixed for the life. Hence, its frequency distribution follows a known pattern governed by gene transmission from generation to generation and varies with the race and geographical distribution of the human being ${ }^{[3]}$. There is strong evidence in the literature to suggest that there is an association between ABO blood group and certain diseases ${ }^{[4]}$. Familial patterns of primary hypertension suggest that there could be some genetic factors for the development of hypertension. There are reports of increased cardiovascular $(\mathrm{CV})$ risks in different blood groups and increase in $\mathrm{BP}$ is considered as a common $\mathrm{CV}$ risk. The $\mathrm{ABO}$ system is one such genetic make-up that can provide much valuable information for early detection of vulnerable groups ${ }^{[5]}$.

The objectives of this study were to evaluate the prevalence of hypertension in various $\mathrm{ABO}$ and $\mathrm{Rh}$ blood group subjects, and to examine any association between $\mathrm{ABO}$ and $\mathrm{Rh}$ blood groups with hypertension.

Methods:

Study design: A cross-sectional study was conducted in Arar city, Northern Saudi Arabia. The study included 312 participants from the general population of Northern Saudi Arabia. Data collection: They were collected using a pre-designed online questionnaire which was distributed among the population. It was selfadministered by participants after a brief 
introduction or explanation of the idea of the research. The questionnaire included the relevant questions to collect data about:

- Socio-demographic characteristics of the participants including age, marital status and educational status

- If the patient has hypertension

- Blood group of participant.

Statistical analysis:

Collected data were coded and analyzed using statistical package for the social sciences (SPSS, version 15). Descriptive statistics for the prevalence and quantitative variables was used. Relation between hypertension and blood group was determined using the chi-square test. Pvalue of less than 0.05 was considered statistically significant.

\section{Ethical considerations:}

This study was reviewed and approved by the Research Ethics Committee of Faculty of Medicine, Northern Border University. Participants were informed that participation is completely voluntary and data collectors introduced and explained the research to participants. No names were recorded on the questionnaires and all questionnaires kept safe.

\section{Results:}

As presented in table (1); $34 \%$ of participants aged between 20- 29 years old, 85.3 of studied population were females, $79.2 \%$ were highly educated and $52.2 \%$ were working.

Table (2) shows that; about $20.5 \%$ of studied sample had hypertension (3.8\% of participants had hypertension for 5- 10 years). $38.1 \%$ had $\mathrm{O}$ blood group, $30.1 \%$ had B blood group, $26 \%$ had A blood group and 5.8\% had AB blood group. $84.9 \%$ of participants were Rh positive. Regarding other chronic diseases; $23.4 \%$ were positive $(8.6 \%$ of them had bronchial asthma, $4.5 \%$ diabetes, $4.5 \%$ severe obesity and $2.2 \%$ had heart diseases).It was found that, 64 $(20.5 \%)$ of the cases had hypertension; from them $20.3 \%$ group $\mathrm{A}, 7.8 \% \mathrm{AB}, 25 \% \mathrm{~B}$ and $46.9 \%$ group $\mathrm{O}$. The present study found that there is no significant association between hypertension and blood groups as a risk factors $(\mathrm{p}=0.274)$. While among hypertensive cases, $85.9 \% \mathrm{Rh}+\mathrm{ve}, 14.1 \% \mathrm{Rh}-\mathrm{ve}$, there is no significant association between hypertension and $\mathrm{Rh}$ factor $(\mathrm{p} \Rightarrow 0.05)$. There was a significant association between hypertension and age group $(\mathrm{P}=0.001)$ and between hypertension with $\operatorname{sex}(\mathrm{P}=0.001)$ as in table (3).
Table (1): Socio-demographic characters of the studied population, Arar, 2018 ( N=312)

\begin{tabular}{|c|l|l|}
\hline Age group & Frequency & Percent \\
\hline$\bullet \quad<20$ & 35 & 11.2 \\
\hline$\bullet \quad 20-29$ & 106 & 34.0 \\
\hline$\bullet \quad 30-39$ & 90 & 28.8 \\
\hline$\bullet \quad 40+$ & 81 & 26.0 \\
\hline Sex & & \\
\hline$\bullet \quad$ Female & 266 & 85.3 \\
\hline$\bullet \quad$ Male & 46 & 14.7 \\
\hline Educational level & & \\
\hline$\bullet \quad$ Primary & 6 & 1.9 \\
\hline$\bullet \quad$ Secondary & 50 & 16.0 \\
\hline$\bullet \quad$ University & 247 & 79.2 \\
\hline$\bullet \quad$ Illiterate & 5 & 1.6 \\
\hline$\bullet \quad$ Preparatory & 4 & 1.3 \\
\hline Marital status & & \\
\hline$\bullet \quad$ Widow & 2 & 6 \\
\hline$\bullet \quad$ Single & 104 & 33.3 \\
\hline$\bullet \quad$ Married & 193 & 61.9 \\
\hline$\bullet \quad$ Divorced & 13 & 4.2 \\
\hline Working status & & \\
\hline$\bullet \quad$ Not & 149 & 47.8 \\
\hline$\bullet \quad$ Working & & 52.2 \\
\hline
\end{tabular}

Table (2): prevalence and period of hypertension, blood group, $\mathrm{Rh}$ factor and other chronic diseases among the studied population, Arar, 2018

\begin{tabular}{|c|c|c|}
\hline Hypertension & No. & $\%$ \\
\hline$\bullet \quad$ Yes & 64 & 20.5 \\
\hline - $\quad$ No & 248 & 79.5 \\
\hline \multicolumn{3}{|l|}{ Period of hypertension (in years) } \\
\hline • $\quad$ No hypertension & 248 & 79.5 \\
\hline - $\quad<1$ & 24 & 7.7 \\
\hline - $1-5$ & 17 & 5.4 \\
\hline - $5-10$ & 12 & 3.8 \\
\hline - $10-15$ & 5 & 1.6 \\
\hline$\bullet \quad>15$ & 6 & 1.9 \\
\hline \multicolumn{3}{|l|}{ Blood group } \\
\hline$\bullet \quad \mathrm{A}$ & 81 & 26.0 \\
\hline - $\mathrm{AB}$ & 18 & 5.8 \\
\hline - $\mathrm{B}$ & 94 & 30.1 \\
\hline - $\mathrm{O}$ & 119 & 38.1 \\
\hline \multicolumn{3}{|l|}{ Rhesus factor (Rh) } \\
\hline • $\quad$ Negative & 47 & 15.1 \\
\hline • $\quad$ Positive & 265 & 84.9 \\
\hline \multicolumn{3}{|l|}{ Other chronic diseases } \\
\hline$\bullet \quad$ No & 239 & 76.6 \\
\hline • Yes & 73 & 23.4 \\
\hline \multicolumn{3}{|c|}{$\begin{array}{l}\text { Main types of other chronic } \\
\text { diseases }\end{array}$} \\
\hline • $\quad$ Diabetes & 14 & 4.5 \\
\hline - $\quad$ Sever obesity & 14 & 4.5 \\
\hline - $\quad$ Heart diseases & 7 & 2.2 \\
\hline - $\quad$ Chronic anemia & 2 & .6 \\
\hline - $\quad$ Bronchial asthma & 27 & 8.6 \\
\hline - $\quad$ Hypothyroidism & 7 & 2.2 \\
\hline - $\quad$ Rheumatoid arthritis & 3 & .6 \\
\hline
\end{tabular}

Table (3): relationship between Hypertension and age, sex, blood group and $\mathrm{Rh}$ factor 


\begin{tabular}{|c|c|c|c|c|}
\hline \multirow[t]{2}{*}{ Variables } & \multicolumn{2}{|c|}{ Hypertension } & \multirow{2}{*}{$\begin{array}{l}\text { Total } \\
(n=21 \\
3)\end{array}$} & \multirow{2}{*}{$\begin{array}{l}\mathbf{P} \\
\text { valu } \\
\mathbf{e}\end{array}$} \\
\hline & $\begin{array}{l}\text { Yes } \\
(n=64 \\
\end{array}$ & $\begin{array}{l}\text { No } \\
(n=24 \\
8)\end{array}$ & & \\
\hline \multicolumn{4}{|l|}{ Age group } & \multirow{9}{*}{$\begin{array}{l}0.00 \\
1\end{array}$} \\
\hline \multirow{2}{*}{$\bullet<20$} & 4 & 31 & 35 & \\
\hline & $6.2 \%$ & $12.5 \%$ & $11.2 \%$ & \\
\hline \multirow[t]{2}{*}{ - $20-29$} & 13 & 93 & 106 & \\
\hline & $\begin{array}{l}20.3 \\
\%\end{array}$ & $37.5 \%$ & $34.0 \%$ & \\
\hline \multirow{2}{*}{ - $\quad 30-39$} & 15 & 75 & 90 & \\
\hline & $\begin{array}{l}23.4 \\
\%\end{array}$ & $30.2 \%$ & $28.8 \%$ & \\
\hline \multirow[t]{2}{*}{ - $40+$} & 32 & 49 & 81 & \\
\hline & $\begin{array}{l}50.0 \\
\%\end{array}$ & $19.8 \%$ & $26.0 \%$ & \\
\hline \multicolumn{4}{|l|}{ Sex } & \multirow{5}{*}{$\begin{array}{l}0.00 \\
1\end{array}$} \\
\hline \multirow{2}{*}{$\begin{array}{ll} & \text { Femal } \\
\mathrm{e}\end{array}$} & 46 & 220 & 266 & \\
\hline & $\begin{array}{l}71.9 \\
\%\end{array}$ & $88.7 \%$ & $85.3 \%$ & \\
\hline \multirow[t]{2}{*}{ - $\quad$ Male } & 18 & 28 & 46 & \\
\hline & $\begin{array}{l}28.1 \\
\%\end{array}$ & $11.3 \%$ & $14.7 \%$ & \\
\hline \multicolumn{5}{|l|}{ Blood group } \\
\hline \multirow[t]{2}{*}{ - $\mathrm{A}$} & 13 & 68 & 81 & \multirow{8}{*}{$\begin{array}{l}0.27 \\
4\end{array}$} \\
\hline & $\begin{array}{l}20.3 \\
\%\end{array}$ & $27.4 \%$ & $26.0 \%$ & \\
\hline \multirow[t]{2}{*}{ - $\mathrm{AB}$} & 5 & 13 & 18 & \\
\hline & $7.8 \%$ & $5.2 \%$ & $5.8 \%$ & \\
\hline \multirow[t]{2}{*}{ - $\mathrm{B}$} & 16 & 78 & 94 & \\
\hline & $\begin{array}{l}25.0 \\
\%\end{array}$ & $31.5 \%$ & $30.1 \%$ & \\
\hline \multirow[t]{2}{*}{ - $\mathrm{O}$} & 30 & 89 & 119 & \\
\hline & $\begin{array}{l}46.9 \\
\%\end{array}$ & $35.9 \%$ & $38.1 \%$ & \\
\hline \multicolumn{4}{|l|}{ Rh } & \multirow{5}{*}{$\begin{array}{l}0.48 \\
9\end{array}$} \\
\hline \multirow{2}{*}{$\begin{array}{ll} & \text { Negati } \\
& \text { ve }\end{array}$} & 9 & 38 & 47 & \\
\hline & $\begin{array}{l}14.1 \\
\%\end{array}$ & $15.3 \%$ & $15.1 \%$ & \\
\hline \multirow{2}{*}{$\begin{array}{ll}\text { - } & \text { Positi } \\
\text { ve }\end{array}$} & 55 & 210 & 265 & \\
\hline & $\begin{array}{l}85.9 \\
\%\end{array}$ & $84.7 \%$ & $84.9 \%$ & \\
\hline
\end{tabular}

\section{Discussion:}

Hypertension has been termed "silent killer", a chronic illness with a long asymptomatic phase that if undetected and untreated silently damages the heart, brain and kidneys. It is estimated to cause 7.1 million deaths globally (13\% of total) ${ }^{[6]}$. Hypertension is dependent on modifiable and non-modifiable factors. Obesity and weight gain are the strongest modifiable independent risk factors in developing hypertension [7]. Familial patterns of hypertension suggests genetic factor as another important non-modifiable predisposing factor, and $\mathrm{ABO}$ blood group is one such factor which needs to be investigated in more details. This was a across sectional study conducted among 312 of studied populations Arar, Northern Saudi Arabia. The study aimed at evaluating the prevalence of hypertension in various $\mathrm{ABO}$ and $\mathrm{Rh}$ blood group subjects, and to determine any association between $\mathrm{ABO}$ and $\mathrm{Rh}$ blood groups with hypertension.

Our study reported, that 64 (20.5\%) of the cases had hypertension; from them $20.3 \%$ group A, $7.8 \% \mathrm{AB}, 25 \% \mathrm{~B}$ and $46.9 \%$ group $\mathrm{O}$. The present study found that there was no significant association between hypertension and blood groups as a risk factors $(\mathrm{p}=0.274)$. In India across sectional study was conducted on 800 subjects, out of which 500 had hypertension; prevalence of blood groups $(\mathrm{B}, \mathrm{O}$ and $\mathrm{AB}$ ) among study subjects with hypertension showing blood group B (39.6\%), followed by $\mathrm{O}(34.6 \%)$, A $(20 \%)$, and $\mathrm{AB}$ $(5.8 \%)$, the frequency of occurrence of hypertension was found to be highest in blood group $\mathrm{B}$ and $\mathrm{O}$, but it was not statistically significant $(p=0.29)$ and concluded that there was no association between $\mathrm{ABO}$ blood groups and essential hypertension ${ }^{[8]}$. In Iran across sectional study was conducted among 510 subjects, from them $208(40.8 \%)$ were hypertensive, and the results showed no association between the ABO blood groups and hypertension $(\mathrm{p}=0.815)$. Therefore, there was no evidence in favor of the hypothesis that $\mathrm{ABO}$ blood groups might be risk factor for hypertension ${ }^{[9]}$. Hospital-based cross-sectional study was carried out on 767 male blood donors to identify the relationship of $\mathrm{ABO}$ blood groups with hypertension It was found that the association between DBP and blood group was statistically significant with $\mathrm{B}+$ in the prehypertensive, $\mathrm{AB}-$ in stage-I hypertension and $\mathrm{A}+$ in the Stage II hypertension categories $(\mathrm{p}<$ $0.05)^{[10]}$. A retrospective study was carried out on 23, 320 blood donors found that, the B blood group was more susceptible to hypertension as compared to blood group $\mathrm{O}$ and $\mathrm{A}$; whereas $\mathrm{AB}$ blood group had less chance of getting hypertension; this could suggest that B group might genetically more prone to hypertension as compared to other groups ${ }^{[11]}$. Another study was carried out in India on 200 medical students and revealed that blood group B was correlated with blood pressure. Moreover, it showed that those with blood group B appeared to be more susceptible to pre-hypertension ${ }^{[12]}$. Kesteloot and Van Houte ${ }^{[13]}$ reported an association between the $\mathrm{ABO}$ blood group and blood pressure among .42,000 Belgian men. They displayed that those with blood type $\mathrm{AB}$ had the highest values of SBP and DBP. In Iraq another 
study conducted among 439 hypertensive patients were chosen from the hypertensive clinic in Sulaimanyia reported that a significant relation between blood group $\mathrm{O}$ and hypertension where $51.2 \%$ of hypertensive patients were group $\mathrm{O}$, while $23.5 \%$ were group A, $19.8 \%$ were group B and $5.2 \%$ were group $\mathrm{AB}$; this mean that group $\mathrm{O}$ people in Sulaimanyia are more prone to have essential hypertension than other blood groups ${ }^{[14]}$. In North India a cross sectional study conducted among 250 postmenopausal women, ranging in age from 45 to 80 years to explore possible associations between $\mathrm{ABO}$ blood group and the risk of hypertension. Analysis of data revealed total prevalence of hypertension was $32 \%$; hypertension was more prevalent in subjects having blood group $\mathrm{O}(10.4 \%)$, followed by blood group A (8.8\%), B (8\%) and least in AB $(4.8 \%)$.The findings of the study suggested that subjects with blood group $\mathrm{O}$ has greater incidence of association with hypertension ${ }^{[15]}$. In earlier studies, from northern part of India observed that $\mathrm{AB}$ blood group individuals had least chance of developing hypertension compared to other groups ${ }^{[16,17]}$. Maxwell and Maxwell found that the chances of hypertension in Glasgow were highest in blood group $\mathrm{O}$ patients (53.04\%), followed by A (33.62\%), then B (11.02\%) and lowest were in $A B$ $(2.32 \%)^{[18]}$. Alam et al. observed no significant difference in systolic and diastolic blood pressure among all blood groups ${ }^{[19]}$.

Our study reported that $85.9 \%$ from hypertensive cases were positive Rh and $14.1 \%$ negative and no association between hyper tension and $\mathrm{Rh}$ factor $(\mathrm{p}=0.489)$. Another study found that among hypertensive cases 93.6\% Rh+ve, 6.4\% Rh-ve;. These conclusions are similar to those of our study. In addition, there was no significant association between hypertension and $\mathrm{Rh}$ factor $(\mathrm{P} \geq 0.05)^{[8]}$.

\section{References:}

1. Saudi Hypertension Management Society (2018): Saudi Hypertension Guideline 2018. King Fahd National Library Cataloguing-in-Publication Data.

https://shms.wildapricot.org/page1561572/5727953

2. Eric HA, Joseph L (2004): Vascular disease and hypertension. In: Andreoli TE, Carpenter CC, Griggs RC, Loscalzo J, editors. Cecil Essentials of
Medicine. $6^{\text {th }}$ ed. University of Michigan: W.B. Saunders Co.

3. Kearney PM, Whelton M, Reynolds K et al. (2005): Global burden of hypertension: Analysis of worldwide data. Lancet, 365:217-23.

4. Reid ME, Lomas-Francis C (2004): The blood group antigen facts book. New York, Elsevier Academic.

5. Garratty G (1994): Do blood groups have a biological role? In Garratty G, ed. Immunology of transfusion medicine. New York, Dekker.

6. Goldman L, Ausiello DA (2003): Cecil Textbook of Medicine ( $22^{\text {nd }}$ ed.) Philadelphia: Saunders: Elsevier Health Sciences.

7. Kasper LD, Braunwald E, Hauser $S$ et al. (2005): Harrison's Principles of Internal Medicine, $16^{\text {th }}$ ed. Vol II. USA: McGrawHill.

8. Kaur M, Kawalpreet Gill K, Bassi $\mathbf{R}$ et al. (2016): Association of $\mathrm{ABO}$ and $\mathrm{Rh}$ blood groups with hypertension ,Pak J Physiol.,12(2):11-14.

9. Tabatabaie AH and Ali-Madadi $M$ (2012): Possible association between $\mathrm{ABO}$ and $\mathrm{Rh}(\mathrm{D})$ blood groups and hypertension. Pak J Med Sci., 28(1):235-237.

10. Varghese A, Abraham ML, Ramachandran $\mathrm{R}$ et al. (2015): A prospective study on the relationship between blood pressure and blood group among adult male blood donors in a Tertiary care center. Int J Clin Exp Physiol., 2:51-5.

11. Chandra T and Gupta A (2012): Association and Distribution of Hypertension, Obesity and ABO Blood groups in Blood Donors. Iran J Ped Hematol Oncol., 2(4):140-145.

12. Supratik B, Ganaraja $B$ and Bhat $R$ (2010): Correlation between the blood groups, BMI and prehypertension among medical students. J Chinese Clin Med.,5:78-82.

13. Kesteloot $H$ and Van Houte $O$ (1974): An epidemiologic survey of arterial blood pressure in a large male population group. Am J Epidemiol.,99:14-29.

14. Nasreen AR (2006): Blood groups and hypertension. J Baghdad Coll Dent.,18(2):68-70. 
Blood groups as risk factor of hypertension in Arar population, Northern Saudi Arabia

15. Kaur M(2014): Association between ABO Blood Group and Hypertension among Post-menopausal Females of North India, The Anthropologist, 17:2, 677-680.

16. Nishi K, Gupta NK and Sharma $S$ (2012): Study on the Incidence of Hypertension and Migraine in $\mathrm{ABO}$ Blood Groups. ISCA J. Biological Sci ., 1(2): 12-16.

17. Sachdev B (2016): Prevalence of hypertension and associated risk factors among Nomad Tribe groups.
Antrocom Online Journal of Anthropology ,7(2):181-189.

18. Maxwell $R$ and Maxwell $K$ (1955): $\mathrm{ABO}$ blood groups and hypertension. BMJ., 16: 179-180.

19. Alam $M$, Wardell $J$ and Anderson $E$ (2000): Effects of first myocardial infarction on left ventricular systolic and diastolic function with the use of mitral annular velocity determined by pulsed wave Doppler tissue imaging, J Am Soc Echocardiogr., 13, 343-352. 